\title{
Class I and II major histocompatibility complex gene product expression by a rat insulinoma cell line in vitro following exposure to gamma interferon
}

\author{
B. Issa-Chergui ${ }^{1}$, A.Goldner-Sauvé ${ }^{1}$, E.Colle ${ }^{1}$, G.J.Prud'homme ${ }^{2}$, P.H.Lapchak ${ }^{2}$, P.H.van der Meide ${ }^{3}$ and \\ T. A. Seemayer ${ }^{1,2}$ \\ ${ }^{1}$ McGill University-Montreal Children's Hospital Research Institute, ${ }^{2}$ Department of Pathology, McGill University, Montreal, Canada and \\ ${ }^{3}$ Primate Center TNO, Rijswijk, The Netherlands
}

\begin{abstract}
Summary. A study of Class I and II major histocompatibility complex gene product expression by a rat insulinoma cell line (RINm5F) was performed using monoclonal antibodies and immunoperoxidase techniques. RINm5F cells were incubated with different concentrations of gamma interferon. RINm5F cells exhibit low levels of Class I molecules and are normally devoid of Class II gene products. Upon exposure to gamma interferon, RINm5F cells showed a dramatic increase in Class I expression. This expression was homogenous and could be detected on all cells after $18 \mathrm{~h}$ of incubation with as little as $1 \mathrm{unit} / \mathrm{ml}$ of interferon. In contrast, de novo Class II expression was not homogeneous and required $36 \mathrm{~h}$ of incubation with $10 \mathrm{units} / \mathrm{ml}$ of interferon. The number of RINm5F cells expressing Class II antigens was dose- and time-dependent. Interferon treatment did not affect the morphology of RINm5F cells as determined by ul-
\end{abstract}

trastructural analysis. Withdrawal of interferon from the culture medium for as long as $78 \mathrm{~h}$ diminished but did not abolish the expression of Class I and Class II molecules already induced. The ability of interferon to enhance expression of Class I gene products and induce de novo expression of Class II molecules on B-cell-derived RINm5F cells supports the hypothesis that aberrant expression of major histocompatibility complex gene products on pancreatic B cells may be an important factor in triggering the immune response in Type 1 (insulin dependent) diabetes mellitus.

Key words: Type 1 (insulin-dependent) diabetes mellitus, rat insulinoma cell line, gamma interferon, immunocytochemistry, major histocompatibility complex gene products, pancreatic B cells.
There now exists a sizable body of evidence which strongly suggests that Type 1 (insulin-dependent) diabetes mellitus is a chronic autoimmune disease [1]. The central event leading to hyperglycaemia is selective and, ultimately, massive B-cell destruction associated with mononuclear cell infiltration of the islets (insulitis) [2]. Both humoral and cellular immune derangements have been implicated as important pathogenetic mechanisms in this process [3].

Major histocompatibility complex (MHC) gene products regulate many immune functions. Class I MHC products, present on the surface of all nucleated cells, control in a restricted fashion the recognition of foreign antigens by cytotoxic T-cells. Class II MHC products are normally present on the surface of only some cells of the immune system (B-lymphocytes, antigen-presenting cells, macrophages, and activated T-lymphocytes). Immune recognition by helper $\mathrm{T}$ - cells, as well as the interactions between helper T-cells and other cells of the immune system, is Class II MHC-restricted.

Type 1 diabetes mellitus is strongly associated with DR3 and DR4 alleles of the human MHC [4], as well as with the RTl.uMHC haplotype in the spontaneous animal model of the disease, the BB rat [4]. It has been proposed that aberrant expression of Class II MHC gene products on endocrine cells could lead to loss of T-cell tolerance to self antigens and thus, to autoimmune disease [5]. Although this is an attractive hypothesis given the immunoregulatory disturbances manifest in the human and, especially, the murine prediabetic state, such aberrant MHC expression on pancreatic B-cells and its role in the pathogenesis of Type 1 diabetes are important but, as yet, unresolved issues.

MHC antigen expression might be affected by viral, chemical, or immune factors [6]. Exposure of a 


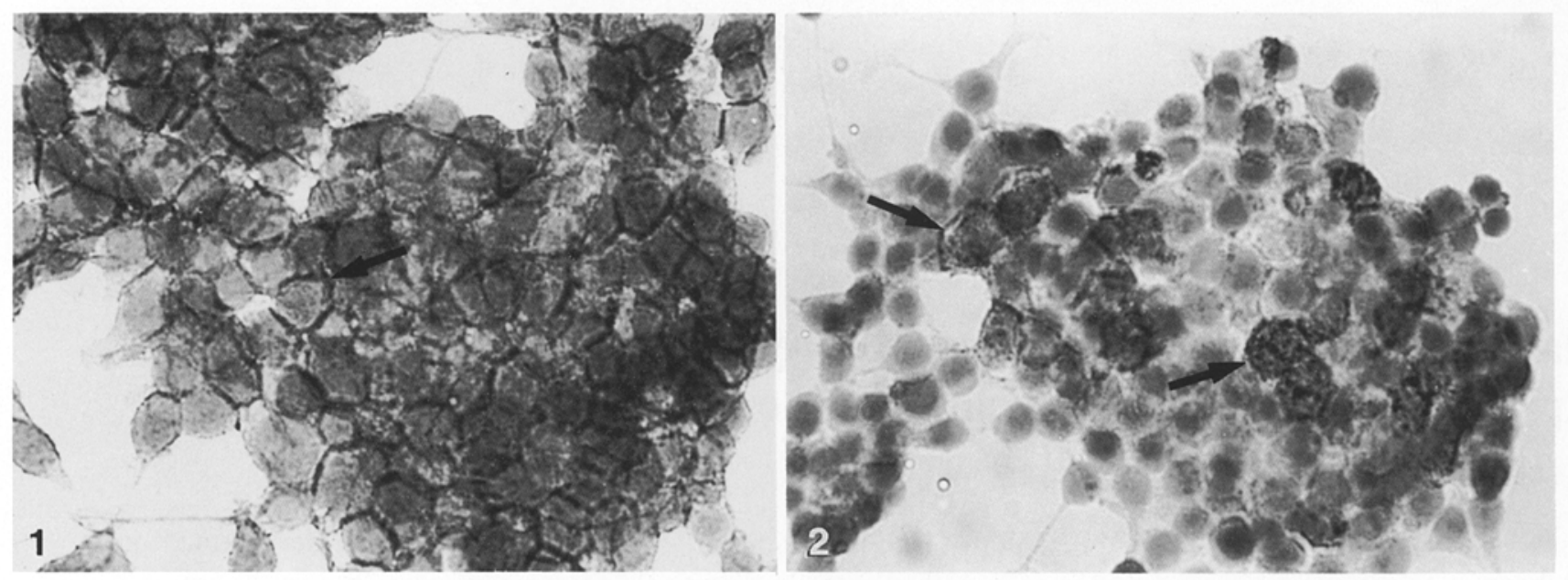

Fig. 1. RINm5F cells stained for Class I MHC antigen expression after incubation with $100 \mathrm{units} / \mathrm{ml}$ of INF $\gamma$ for $48 \mathrm{~h}$ (X400). Arrow points to cell surface positive staining

Fig. 2. RINm5F cells stained for Class II MHC antigen expression after incubation with 1000 units/ml of INF $\gamma$ for $96 \mathrm{~h}$ (X400). Arrow points to cell surface positive staining

variety of cell types to interferon gamma (IFN $\gamma$ ), a lymphokine released by activated T-lymphocytes, induces an increase in both Class I and Class II MHC antigen expression [7].

Using immunoperoxidase techniques, we have investigated the ability of a rat tumour cell line derived from B cells (RINm5F) to express MHC gene products after incubation with rat IFN $\gamma$. We have also studied the chronological development of this expression, its relation to the concentration of IFN $\gamma$, and the effects of withdrawal of INF $\gamma$ on MHC expression.

\section{Materials and methods}

\section{Cell line}

The RINm5F cell line used in this study was obtained from a radiation-induced rat islet cell tumour [8]. This cell line was provided by Dr. H.K. Oie (National Cancer Institute, Bethesda, Md, USA) and was maintained in RPMI-1640 (Gibco, Burlington, Ont, Canada) supplemented with $24 \mathrm{mmol} / 1$ sodium bicarbonate, $5 \mathrm{mmol} / 1$ Hepes, $2 \mathrm{mmol} / 1$ glutamine, $50 \mathrm{IU} / \mathrm{ml}$ penicillin, $50 \mathrm{mcg} / \mathrm{ml}$ streptomycin and $10 \%$ fetal calf serum (RIN medium).

\section{Interferon treatment}

The purification and characterisation of the rat gamma interferon employed in this study are described elsewhere [9, 10].

Cells were incubated in 4 chamber Lab-Tek slides (Flow Labs, Mississauga, Ont, Canada) in the presence of rat IFN $\gamma$ diluted in RIN medium $(0,1,10,100$ and 1,000 units per milliliter). Cells were exposed to IFN $\gamma$ for up to $96 \mathrm{~h}$. Samples were obtained at 1 or $2 \mathrm{~h}$ intervals for the early stage (first $24 \mathrm{~h}$ ) of the experiment and at $10-12 \mathrm{~h}$ intervals at the late stage (after $24 \mathrm{~h}$ ) of the experiment.

To determine whether MHC expression required constant exposure to INF $\gamma$, withdrawal studies were performed. After $18 \mathrm{~h}$ of incubation the interferon-containing medium was replaced with RIN
Table 1. Number of OX 6 positive RINm5F cells after: A) incubation with 10 , or 100 units $/ \mathrm{ml}$ of INF $\gamma$. B) initial $18 \mathrm{~h}$ of induction period, followed by withdrawal of 10 or 100 units $/ \mathrm{ml}$ of INF $\gamma$ from the culture medium (withdrawal time is given between brackets)

\begin{tabular}{|c|c|c|c|c|c|}
\hline \multirow[b]{2}{*}{ A) } & \multicolumn{5}{|c|}{ Duration of INF $\gamma$ treatment (h) } \\
\hline & 24 & 36 & 48 & 72 & 96 \\
\hline $\begin{array}{l}\text { Incubation with } \\
10 \text { units } / \mathrm{ml} \text { of } \\
\text { INF } \gamma\end{array}$ & 0 & 134 & 215 & 273 & 338 \\
\hline $\begin{array}{l}\text { Incubation with } \\
100 \mathrm{units} / \mathrm{ml} \\
\text { of INF } \gamma\end{array}$ & 0 & 189 & 1012 & 1540 & 2300 \\
\hline B) & $\begin{array}{l}24 \\
(6)\end{array}$ & $\begin{array}{c}36 \\
(18)\end{array}$ & $\begin{array}{c}48 \\
(30)\end{array}$ & $\begin{array}{c}72 \\
(54)\end{array}$ & $\begin{array}{c}96 \\
(78)\end{array}$ \\
\hline $\begin{array}{l}\text { After withdrawal } \\
\text { of } 100 \text { units } / \mathrm{ml} \\
\text { of INF } \gamma\end{array}$ & 0 & 92 & 506 & 298 & 112 \\
\hline $\begin{array}{l}\text { After withdrawal } \\
\text { of } 10 \text { units } / \mathrm{ml} \text { of } \\
\text { INF } \gamma\end{array}$ & 0 & 51 & 77 & 28 & 2 \\
\hline
\end{tabular}

medium alone. The withdrawal periods studied were $6,18,30,54$, and $78 \mathrm{~h}$.

After culture, the slides were rinsed with phosphate buffered saline (PBS) and fixed for $5 \mathrm{~min}$ in acetone.

\section{Immunoperoxidase techniques}

Mouse monoclonal antibody (MAb) OX18 detects a common determinant of rat MHC Class I (RTl.A) antigens. Mouse MAb OX6 detects a common determinant of rat MHC Class II (RT1.B) antigens. MAb's used were affinity-purified IgG from ascites (OX18) or supernatants (OX6). MAb OX18 was diluted 1/200 and was applied for $90 \mathrm{~min}$. MAb OX6 was diluted $1 / 10$ and was applied for $60 \mathrm{~min}$.

Cellular binding of OX18 was detected by an indirect immunoperoxidase method using peroxidase-conjugated $F\left(a b^{\prime}\right) 2$ frag. 


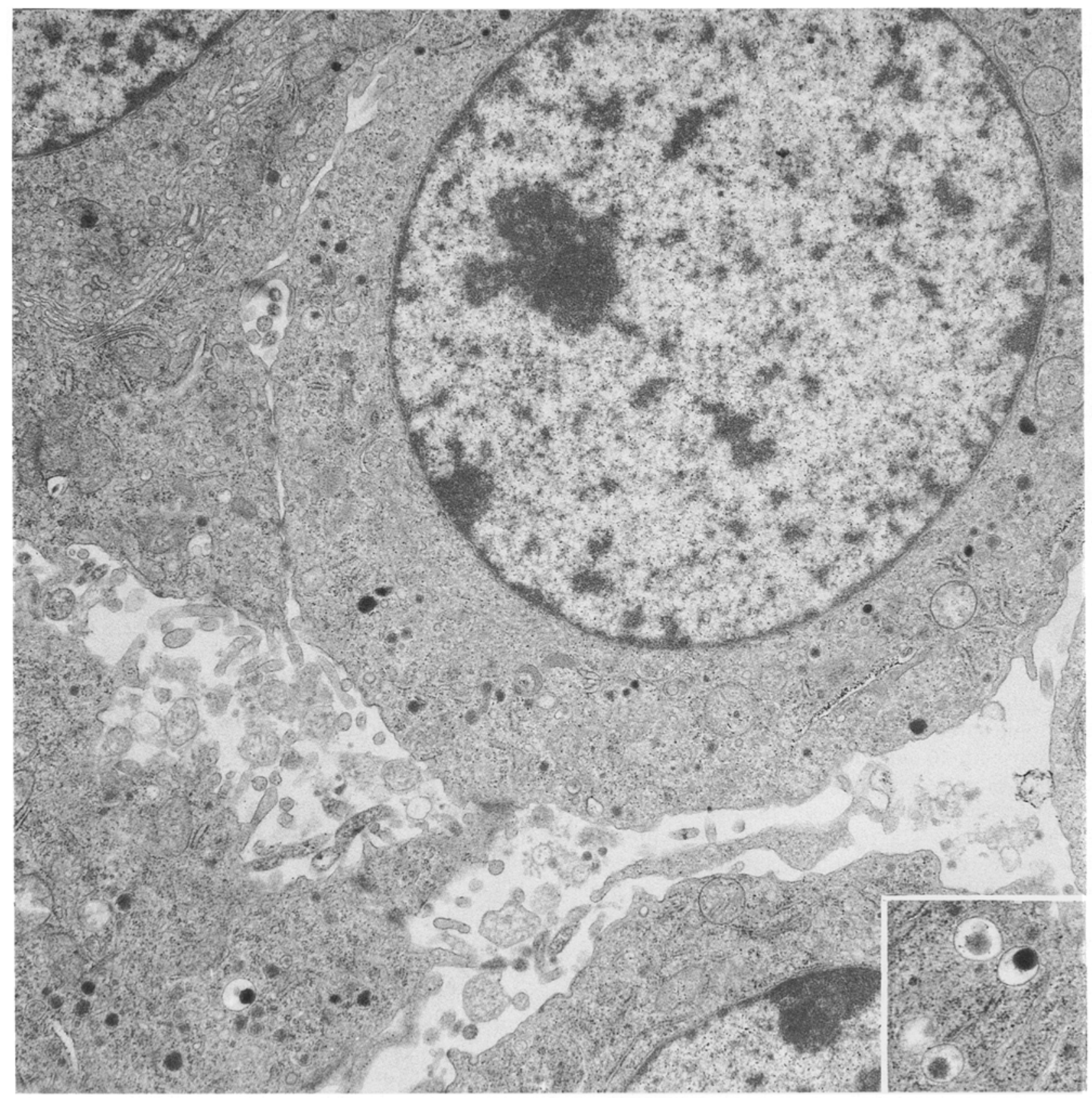

Fig. 3. Electronmicrograph of RINm5F cells following exposure to 100 units $/ \mathrm{ml}$ IFN $\gamma$ for $48 \mathrm{~h}$. $(\times 14,500)$. Inset shows typical insulin granules $(\times 24,000)$

ment goat anti-mouse $\operatorname{IgG}\left(\mathrm{F}\left(\mathrm{ab}^{\prime}\right) 2\right.$ fragment specific) (Cappell Sci. Div., Cooper Biochemical, Malvern, Penn, USA) diluted $1 / 160$ and applied for $90 \mathrm{~min}$.

Cellular binding of OX6 was detected by the Avidin-Biotin three layer method $(\mathrm{ABC})$ using affinity-purified biotinylated horse antimouse IgG (heavy and light chains) diluted $1 / 200$ and applied for $1 \mathrm{~h}$. A third layer consisting of peroxidase conjugated Avidin-Biotin complex was applied for an additional hour (standard kit). MAb's and Avidin-Biotin reagents were obtained from Dimension Labs, Mississauga, Ont, Canada.

To prevent non-specific binding, antibodies and conjugates were diluted in PBS containing 0.1\% bovine serum albumin and $10 \%$ normal rat serum.

After washing, the reaction product was revealed by exposure to 3.3' diaminobenzidine tetrahydrochloride (Sigma Chemicals, St. Louis, Mo, USA) for 4-10 min.
Staining to detect Class I and Class II molecules was performed at each time point and IFN $\gamma$ concentration. Two negative controls were used: (1) cells treated with RIN medium alone and (2) slides in which the primary antibody was omitted. Positive controls were represented by normal rat spleen sections.

The OX6 stained chamber-slides were screened systematically to determine the number of Class II positive RIN cells. Each slide is composed of 4 identical $(2 \times 0.89 \mathrm{~cm})$ culture chambers. Counting was performed using a graticule $19 \mathrm{~mm}$ diameter (Wild Leitz Canada, Montréal, Québec, Canada) inserted into the ocular of the microscope to avoid overlap of fields. Screening was carried out under the $\times 40$ objective. At this power each field covered by the grid represents $4 \mathrm{~mm}^{2}$ of slide surface. Counts were given as the number of positive cells per unit surface area, considered in this experiment to be the standard $(2 \times 0.89 \mathrm{~cm})$ bottom surface area of the culture chamber $(44.5$ grids or fields at $\times 40)$. 


\section{Electron microscopy}

Two samples consisting of RINm5F cells with RIN medium alone and RINm5F cells incubated with 100 units/ml of IFN $\gamma$ for $48 \mathrm{~h}$ were processed as usual for routine electron microscopic study [11]. Ultra-thin sections were doubly-stained with uranyl acetate and lead citrate, mounted on grids, and examined in a Philips EM201 electron microscope (Philips Electronic Instruments, Mount Vernon, NY, USA).

\section{Statistical analysis}

The time course study was repeated four times in order to evaluate reproducibility. The data obtained at the various time points and IFN $\gamma$ concentrations were comparable. A representative set of data, that in which the greatest number of time points was studied, is presented.

\section{Results}

\section{Immunohistochemistry}

RINm5F cells cultured in RIN medium alone showed very low levels of Class I MHC antigen expression. No definite cell surface staining was observed. Furthermore, staining to detect Class II MHC molecules revealed totally negative cells.

Enhancement of Class I expression started at $8 \mathrm{~h}$ of incubation with 10 units/ml of IFN $\gamma$. Ten to $20 \%$ of the cells exhibited sharply-outlined cell surface Class I expression at $8 \mathrm{~h}$ of incubation with 10 units $/ \mathrm{ml}$ of IFN $\gamma$. The percentage of cells expressing Class I MHC molecules on their surface increased in proportion to the dose and duration of IFN $y$ treatment. Expression of Class I molecules on all RINm5F cells was attained at $18 \mathrm{~h}$ of incubation with as little as $1 \mathrm{unit} / \mathrm{ml}$ of IFN $\gamma$. Following this period the intensity of the reaction product remained stable (Fig.1) and was not reduced after withdrawal of IFN $\gamma$ from the culture medium for as long as $78 \mathrm{~h}$.

Staining to detect Class II MHC molecules revealed very few positive cells at $36 \mathrm{~h}$ of incubation with IFN $\gamma$. The reaction product was present at the cell surface (Table 1). Ten units/ml of IFN $\gamma$ was the lowest dose of IFN $\gamma$ capable of inducing Class II MHC expression. The percentage of positively-stained cells increased in proportion to the dose and duration of IFN $\gamma$ incubation, however only focal expression of Class II MHC antigens was observed at $96 \mathrm{~h}$ incubation using 1000 units $/ \mathrm{ml}$ of IFN $\gamma$ (Fig. 2). Withdrawal of IFN $\gamma$ from the culture medium for up to $78 \mathrm{~h}$ did not abolish the Class II expression already induced.

\section{Electron microscopy}

At the ultrastructural level, the RINm5F cells were variable in size, with a large nucleus and sometimes prominent nucleolus. Rough endoplasmic reticulum was abundant. The mitochondria were large, rounded and numerous. Secretory granules were less numerous than in normal B cells, although typical insulin granules were seen. Also, occasional delta (somatostatin) granules could be identified.

Treatment with IFN $\gamma$ had no recognisable adverse effect on the ultrastructural features of the RINm5F cells (Fig.3).

\section{Discussion}

Major histocompatibility antigens have been induced by others on pancreatic endocrine cells using interferon gamma. Campbell et al. reported enhanced Class I MHC expression on human and mouse pancreatic B cells [12, 13] as well as on RINm5F cells following IFN $\gamma$ treatment [14]. Class II MHC antigens have been induced on cultured murine islets $[15,16]$, B cells isolated from $\mathrm{BB} / \mathrm{E}$ rats [17], and RIN cells $[18,19]$; IFN $\gamma$, as well as lymphokine supernatants, were used in these experiments. Finally, a recent report describes the induction of Class II MHC molecules on cultured human islets exposed to IFN $\gamma$ and tumour necrosis factor or lymphotoxin [20].

In vivo studies in our laboratory with the spontaneously diabetic $\mathrm{BB}$ rat demonstrated marked expression of Class I MHC molecules on B cells in islets infiltrated by mononuclear cells. This increased Class I expression was detected even at a prediabetic stage. Pancreata free of an infiltrate were devoid of insular staining or expressed Class I molecules only weakly on B cells. However, we have been consistently unable to demonstrate Class II MHC antigens on pancreatic endocrine cells.

Using lymphokine supernatants we were previously unable to induce Class II MHC molecules on RINm5F cells. This failure could be due in part to the low sensitivity of the indirect immunoperoxidase technique employed and/or the limited time of incubation. Nevertheless, we have been able to induce an increase in Class I MHC molecules on RINm5F cells using supernatants of Concanavalin A-activated spleen cells.

In this study we determined the time course of expression of both classes of MHC antigens on a line of RINm5F cells after treatment with recombinant rat IFN $\gamma$. Light microscopic immunocytochemistry was utilised to determine this expression as opposed to flow cytometry, since the former can detect small numbers of immunoreactive cells, whereas the latter requires a greater number of positive cells in order to be detected above background levels. Indeed, small numbers of positive cells were noted by light microscopy at $36 \mathrm{~h}$ in our study, whereas positive cells were not detectable until $72 \mathrm{~h}$ with flow cytometric techniques [19]. Enhancement of Class I MHC antigen expression did not require large amounts of IFN $\gamma$, occurred early, 
and was intense and homogeneously distributed. In contrast, de novo Class II MHC antigen expression required a relatively high dose of INF $\gamma$, occurred late, and was focal and less intense than Class I expression. Induction of Class II MHC molecules was dependent on both incubation time and the concentration of IFN $\gamma$. Time effect was prominent using high concentrations of INF $\gamma$. The number of OX6 positive RINm5F cells increased 1.5 fold between 48 and $96 \mathrm{~h}$ using $10 \mathrm{units} / \mathrm{ml}$ of IFN $\gamma$, while it increased 2.2 fold between the same time points using 100 units $/ \mathrm{ml}$ of INF $\gamma$, probably indicating an additive effect of time and INF $\gamma$ concentration on induction.

The finding of MHC Class II positive RINm5F cells in the $30 \mathrm{~h}$ withdrawal period might be explained by the fact that INF $\gamma$ was diluted by the replacement RIN medium but not totally withdrawn. The remaining IFN $\gamma$ in the medium (not evaluated) may have contributed to Class II expression and, hence, a number of positive RINm5F cells, albeit less than the numbers obtained using the induction experimental conditions.

Inappropriate expression of insular MHC antigens has been implicated as an important factor in the pathogenesis of the selective immune attack on B cells in Type 1 diabetes. The role of such expression remains very controversial. Some regard this phenomenon as causative to B-cell injury [21], whereas others view it as secondary to the insular ingress of cells of the immune system and subsequent release of various lymphokines [22]. This controversy might stem from the fact that animal models could be different from the human disease. Another source of confusion might be the difference between events which are taking place in vivo and the in vitro conditions employed. While RINm5F cells are tumour-derived and, as such, might exhibit biological properties different from normal B cells, this study suggests that both classes of MHC antigens might be pivotal in the sequence of events leading to loss of insulin-secreting cells. Thus, Class I MHC expression might provide an early signal to the immune system, while Class II MHC molecules could offer a later stimulus. Support for this hypothesis stems not only from this in vitro study but our in vivo finding of enhanced Class I expression in islets from $\mathrm{BB}$ rats prior to disease onset [23].

The failure to detect Class II gene expression in vivo might be due to the focal nature of this expression and/or the limited amount of pancreatic tissue available for study. Alternatively, it is possible that such expression, although lasting for at least $24 \mathrm{~h}$ in this study, may represent a transient event, a fact supported by the findings of Scheymius et al. on rat keratinocytes [24]. Indeed, the role of Class II MHC molecules in the pathogenesis of Type 1 diabetes has been emphasized by several investigators $[25,26]$. In the latter report, Prud'homme et al. were able to inhibit islet cell antigen recognition by $\mathrm{T}$-cells in the $\mathrm{BB}$ rat by a monoclonal antibody directed against the Class II D region of the rat MHC (analogous to human DR). Furthermore, interleukin 2, which is produced upon activation of Class II MHC-restricted T-helper lymphocytes, is reported to increase the incidence of Type 1 diabetes in $\mathrm{BB}$ rats [27].

The impact of various cytokines on pancreatic islets is an issue of importance, not only in relation to MHC gene product induction, but also because such cytokines may have direct cytotoxic properties on islet cells. In our study, no features of cell injury were detected ultrastructurally in our culture system. Pukel et al. report that 100 units $/ \mathrm{ml}$ of murine IFN $\gamma$ have a small dose-dependent lytic effect on cultured rat islets [28]. However, cytotoxic effects, which they determined by cell lysis and phase contrast microscopy, were markedly increased following exposure to combinations of cytokines such as tumour necrosis factor (or lymphotoxin) and interleukin-1, tumour necrosis factor (or lymphatoxin) and IFN $\gamma$, or interleukin-1 and INF $\gamma$. Thus, a pronounced synergism exists amongst cytokines in relation to insular cytotoxicity.

Further experiments to establish the time course of MHC gene expression (at the transcriptional and translational level) on islet cells in young $\mathrm{BB}$ rats are in progress to elucidate the role of MHC genes in the sequence of events that leads to Type 1 diabetes.

Acknowledgments. This work was supported by grants (MA-7636 and PG25) from the Medical Research Council of Canada. Dr. IssaChergui is the recipient of a fellowship from the McGill UniversityMontreal Children's Hospital Research Institute. Dr. Goldner-Sauvé is the recipient of a fellowship from the Diabetic Children's Foundation. Dr. Seemayer is the recipient of the McPherson, Fraser Monat University Associateship.

\section{References}

1. Eisenbarth GS (1986) Type I diabetes mellitus, a chronic autoimmune disease. N Engl J Med 314: 1360-1368

2. Cahill GF JR, McDewitt HO (1981) Insulin-dependent diabetes mellitus: the initial lesion. N Engl J Med 304: 1454-1465

3. Bottazzo GF (1984) B-cell damage in diabetic insulitis: are we approaching a solution? Diabetologia 26: 241-249

4. Colle E, Guttmann RD, Fuks A, Seemayer TA, Prud'homme GJ (1986) Genetics of the spontaneous diabetic syndrome: interaction of MHC and non-MHC associated factors. Mol Biol Med 3: 13-23

5. Hanafusa T, Chiovato L, Doniach D, Pujol-Borrell R, Russell RCG, Bottazzo GF (1983) Aberrant expression of HLA-DR antigen on thyrocytes in Graves' disease: relevance for autoimmunity. Lancet II: $1111-1115$

6. Halloran PF, Wadgymar A, Autenried P (1986) The regulation of expression of major histocompatibility complex products. Transplantation $41: 413-420$

7. Skoskiewics MJ, Calvin RB, Schneeberger EL, Russell PS (1985) Widespread and selective induction of major histocompatibility complex-determined antigens in-vivo by $\gamma$-interferon. J Exp Med 162: $1645-1664$

8. Gazdar AF, Chick WL, Oie HK, Sims HL, King DL, Weir GC, Lauris V (1980) Continuous clonal, insulin- and somatostatin secreting cell lines established from a transplantable rat islet cell tumor. Proc Natl Acad Sci USA 77: 3519-3523 
9. Dijkema R, van der Meide $\mathrm{PH}$, Dubbeld $\mathrm{M}$, Caspers $\mathrm{M}$, Wubben J, Schellekens H (1986) Cloning, expression and purification of rat IFN $\gamma$. Meth Enzymol 119: 453-464

10. Van der Meide PH, Dubbeld M, Vijverberg K, Kos T, Schellekems $H$ (1986) The purification and characterization of rat gamma interferon by use of two monoclonal antibodies. J Gen Virol 67: 1059-1071

11. de Chadarévian J-P, Corriveau M (1987) Characteristic cytoplasmic surface activity (CCSA) in benign and leukemic bone marrow cells. Hum Pathol 18: 361-367

12. Campbell JL, Bizili K, Colman PC, Tuch BE, Harrison LC (1986) Interferon $\gamma$ induces the expression of HLA-A, B, C but not HLA-DR on human pancreatic beta cells. J Clin Endocrinol Metab 62: 1101-1109

13. Campbell JL, Wong GHW, Schrader JW, Harrison L (1985) Interferon $\gamma$ enhances the expression of the major histocompatibility Class I antigens on mouse pancreatic beta cells. Diabetes 34: 1205-1209

14. Campbell JL, Harrison C, Colman PG, Papaioannou J, Ashcroft RG (1986) Expression of Class I MHC proteins on RINm5F cells is increased by interferon and lymphokine-conditioned medium. Diabetes 35: 1225-1228

15. Wright JR, Lacy PE, Unanue ER, Muszynski C, Hauptfeld V (1986) Interferon-mediated induction of Ia antigen expression on isolated murine whole islets and dispersed islet cells. Diabetes 35: 1174-1177

16. Wright JR, Epstein HR, Hauptfeld V, Lacy PE (1988) Tumor necrosis factor enhances interferon-induced Ia antigen expression on murine islet parenchymal cells. Am J Pathol 130: 427-430

17. Walker R, Cooke A, Bone AJ, Dean BM, van der Meide P, Baird JD (1986) Induction of Class II MHC antigens in vitro on pancreatic B-cells isolated from BB/E rats. Diabetologia 29: $749-751$

18. van Vliet E, Molenaar JL, Bruining GJ, Vries RRP (1987) Recombinant $\gamma$-interferon induces Class II major histocompatibility complex antigens on insulinoma cells. Tissue Antigens 29: $195-200$

19. Varey A-M, Lydyard PM, Dean BM, van der Meide PH, Baird JD, Cooke A (1988) Interferon $\gamma$ induces Class II MHC antigens on RINm5F cells. Diabetes 37: 209-212

20. Pujol-Borrel R, Todd I, Doshi M, Bottazzo GF, Sutton R, Gray D, Adolf GT, Feldmann M (1987) HLA Class II induction in human islet cells by interferon-gamma plus tumour necrosis factor or lymphotoxin. Nature 326: 304-306

21. Foulis AK, Farquharson MA (1986) Aberrant expression of HLA-DR antigens by insulin-containing B-cells in recent-onset type 1 diabetes mellitus. Diabetes 35: 1215-1224

22. Dean BM, Walker RJ, Bone AJ, Baird JD, Cooke A (1985) Prediabetes in the spontaneously diabetic $\mathrm{BB} / \mathrm{E}$ rat: lymphocyte subpopulations in the pancreatic infiltrate and expression of rat MHC Class II molecules in endocrine cells. Diabetologia 28: $464-466$

23. Ono SJ, Issa-Chergui B, Colle E, Seemayer TA, Guttmann RD, Fuks A (1987) Class I MHC expression is enhanced in the pancreatic islets of prediabetic BB rats. Transplant Proc 19: 3187-3189

24. Scheynius A, Johannsson C, van der Meide PH (1986) In vivo induction of I a antigens on rat keratinocytes by gamma-interferon. Br J Dermatol 115: 543-549

25. Boitard C, Michie S, Serrurier P, Butcher GW, Larkin AP, McDevitt HO (1985) In vivo prevention of thyroid and pancreatic autoimmunity in the BB rat by antibody to Class II major histocompatibility complex gene products. Proc Natl Acad Sci USA 82: 6627-6631

26. Prud'homme GJ, Colle E, Fuks A, Guttmann RD (1987) Major histocompatibility complex restriction of T-lymphocyte responses to islet cell antigens in IDDM rats. Diabetes 36: 237-239

27. Kolb H, Zielasek J, Treichel U, Freytag G, Wrann G, Kiesel U (1986) Recombinant interleukin 2 enhances spontaneous insulindependent diabetes in BB rats. Eur J Immunol 16: 209-212

28. Pukel C, Baquerizo H, Rabinovitch A (1988) Destruction of rat islet cell monolayers by cytokines: synergistic interactions of interferon $\gamma$, tumor necrosis factor, lymphotoxin, and interleukin 1. Diabetes 37: 133-136

Received: 29 December 1987

and in revised form: 16 May 1988

Dr. T.A. Seemayer

Department of Pathology

The Montreal Children's Hospital

2300 Tupper Street

Montréal, Québec H3H 1P3

Canada 